\title{
To Serve ANd Protect WhOM? Proximity in Cases of Police Failure to Protect
}

\author{
ERIKA CHAMBERLAIN ${ }^{*}$
}

This article examines the duty of care owed by police to potential victims of crime, focusing specifically on the issue of proximity. The author surveys both Canadian and UK cases in order to examine the factors that potentially give rise to a special relationship in these circumstances, and compares the Canadian courts' more plaintiff-friendly approach to the English courts' persistent refusal to recognize proximity in the relationship between the police and victims of crime. The case law is then analyzed in order to shed light on the utility and content of the proximity requirement for the duty of care, taking into consideration the factual context, statutory framework, and policy considerations.

\section{TABle OF Contents}

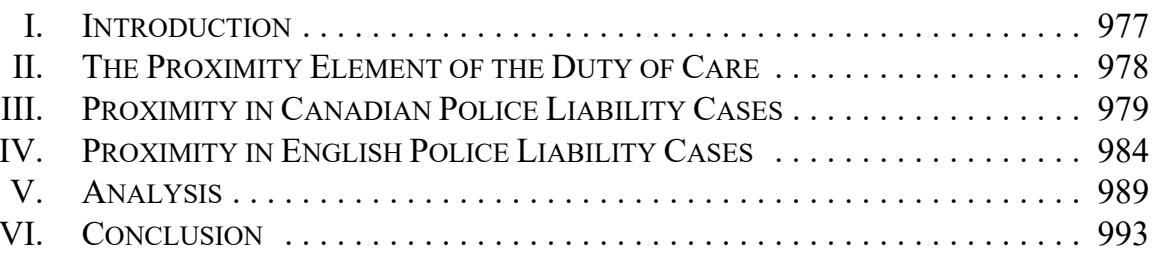

\section{INTRODUCTION}

It is an honour to contribute to this volume celebrating Professor Klar, whose scholarship has shaped the development of Canadian tort law. I have long admired his ability to bring clarity and order to a sometimes perplexing body of law, and especially to the analysis of the duty of care in situations involving statutory obligations. I have chosen to address one such situation in this article: the duty of care owed by police to potential victims of crime. While much has been written about the various policy considerations that justify (or refute) police immunity for their failure to prevent crime, the present article focuses instead on the element of proximity. ${ }^{1}$ It examines the factors that potentially give rise to a "special relationship" in these cases, such as the plaintiff's inclusion in a narrow class of potential victims and her personal interactions with police, and compares the Canadian courts' more plaintiff-friendly approach to the English courts' persistent refusal to recognize proximity in the police and crime victim relationship. The factual context and statutory framework of claims for police failure to protect also provide broader insight into the utility of proximity as an element of the duty of care test, and its interaction with policy considerations.

LLB, PhD, Associate Dean (Academic) and Associate Professor, Faculty of Law, Western University. I would like to thank John Petrella, JD Candidate 2017, for his valuable assistance in preparing this article.

See e.g. Catherine Moroz, "Jane Doe and Police Liability for Failure to Apprehend: The Role of the Anns Public Policy Principle in Canada and England" (1995) 17:3 Adv Q 261; Laura CH Hoyano, "Policing Flawed Police Investigations: Unravelling the Blanket" (1999) 62:6 Mod L Rev 912; Dermot PJ Walsh, "Police Liability for a Negligent Failure to Prevent Crime: Enhancing Accountability by Clearing the Public Policy Fog" (2011) 22:1 King's LJ 27. 


\section{The Proximity Element of The DUty of CARe}

The current framework for analyzing the duty of care in negligence was established by the Supreme Court of Canada in Cooper v. Hobart, ${ }^{2}$ and involves the analysis of three main elements: reasonable foreseeability, proximity, and so-called "residual" policy considerations. The Court declined to provide a definition of proximity, but noted that it includes factors like "expectations, representations, reliance, and the property or other interests involved." "In cases involving public authority defendants, the proximity analysis should be rooted in the context of the governing statute, which is the primary source of the defendant's obligations. ${ }^{4}$ In the years since Cooper, this approach to proximity has frequently led courts to find that there is no duty of care owed by the relevant public authority. Because many statutory obligations are phrased broadly, with the public interest in mind, they are unlikely to create private law duties of care toward individual plaintiffs.

For example, in Eliopoulos Estate v. Ontario (Minister of Health and Long Term Care), ${ }^{5}$ Justice Sharpe explained that the statutory obligations on the Minister to promote the health of Ontario residents and to prevent the spread of infectious diseases did not give rise to a private law duty toward a man who died from complications related to the West Nile Virus. Similarly, in Attis v. Canada (Minister of Health), ${ }^{6}$ Justice Lang found that the Minister did not owe a duty of care to women who suffered injuries on the rupture of breast implants. Although Health Canada had the power to enforce regulations prohibiting the sale of unsafe medical devices, there was no obligation to do so. Justice Lang reasoned that the Department of Health $\mathrm{Act}^{7}$ indicates that "the Minister's obligations are to the people of Canada for the promotion of their health and the prevention of risk generally. Thus ... the Minister's duty is to the people of Canada as a whole, not to individual residents." 8 These cases illustrate that the more broadly the statutory duties are phrased, and the more a defendant has to consider the public interest, the less likely it is that the defendant will owe a private law duty of care toward those who suffer loss as a result of its negligence. Or, as one author has suggested, a duty to all is a duty to none. ${ }^{9}$

In the case of police duties toward victims of crime, the relevant statutory obligations are usually framed in terms of "preserving the peace," "maintaining law and order," "preventing crimes and other offences," and "assisting victims of crime."10 These duties clearly have a

2001 SCC 79, [2001] 3 SCR 537 [Cooper].

Ibid at para 34. The Court explained that the factors affecting proximity are diverse: "One searches in vain for a single unifying characteristic" (ibid at para 35 ).

Ibid at para 43. Professor Klar has been critical of this approach, which tends to conflate statutory and common law duties. See Lewis Klar, "Breach of Statute and Tort Law" in Jason W Neyers, Erika Chamberlain \& Stephen GA Pitel, eds, Emerging Issues in Tort Law (Oxford: Hart Publishing, 2007) 31; Lewis Klar, "The Tort Liability of the Crown: Back to Canada v Saskatchewan Wheat Pool" (2007) 32:3 Adv Q 293; Lewis Klar, "Syl Apps Secure Treatment Centre v. B.D.: Looking for Proximity within Statutory Provisions" (2007) 86:2 Can Bar Rev 337.

5 (2006), 82 OR (3d) 321 at para 17 (CA). The relevant statute is the Health Protection and Promotion Act, RSO 1990, c H.7. See also Williams v Canada (Attorney General) (2005), 76 OR (3d) 763 (Sup Ct J), aff'd in part (2009), 95 OR (3d) 401 (CA) (involving a similar action by victims of the SARS outbreak in Toronto).

2008 ONCA 660, 93 OR (3d) 35 [Attis].

SC 1996, c 8, s 4 .

Attis, supra note 6 at para 54 .

Neville McClure, "Duty to All and Duty to None: Jane Doe v. Board of Commissioners of Police for the Municipality of Metropolitan Toronto" (1990) 48:1 UT Fac L Rev 168 at 168.

See e.g. Police Services Act, RSO 1990, c P.15, s 42(1); Police Act, SNB 1977, c P-9.2, s 12(1). 
public element to them, and there is no doubt that police must balance competing interests when allocating human and financial resources to crime prevention, investigations, and the apprehension of criminal suspects. Thus, it would not be surprising if the courts were to interpret these statutory duties as insufficient to give rise to a proximate relationship with individual plaintiffs. As discussed below, this is precisely what the English courts have done. In Canada, however, the courts have been willing to analyze these statutory obligations as they apply to individual cases where potential victims are identifiable or have had direct contact with police. There is general acknowledgment that police can owe a private law duty of care to some victims of crime; the primary question is what makes a victim sufficiently identifiable to benefit from that duty.

\section{Proximity in Canadian Police Liability Cases}

Probably the best-known Canadian case dealing with police liability for failure to protect or warn crime victims is Doe v. Metropolitan Toronto (Municipality) Commissioners of Police. ${ }^{11}$ The plaintiff was attacked by the so-called "Balcony Rapist," who had committed a series of sexual assaults on single, white women living in the Church-Wellesley area of Toronto. In each case, the rapist gained access through the balcony door of a second or thirdfloor apartment. The police were aware of the rapist's pattern, but apparently chose not to warn women in the area for fear that they would become hysterical and that this hysteria would cause the rapist to flee, thereby compromising the investigation. To use the plaintiff's words, the police used the women as "bait" for the rapist. She sued both in negligence and for breach of her rights under sections 7 and 15 of the Charter of Rights and Freedoms. ${ }^{12}$

Justice Moldaver (as he then was) examined the alleged duty of care owed by police in light of the statutory context. Specifically, section 57 of the then Police Act ${ }^{13}$ imposed a duty on police to preserve the peace, prevent crime, and apprehend offenders. Justice Moldaver noted that these statutory obligations do not normally impose a duty of care:

For the most part, the police are free to go about their task of detecting and apprehending criminals without fear of being sued by individual members of society who have been victimized. The reason for this is simple. While the police owe certain duties to the public at large, they cannot be expected to owe a private law duty of care to every member of society who might be at risk. ${ }^{14}$

However, a duty of care could exist where there was a proximate relationship between the police and the plaintiff. In finding that there was sufficient proximity in Doe, Justice Moldaver stressed that the plaintiff was "part of a narrow and distinct group of potential victims." 15 Given that the rapist confined his attacks to a small geographical area and a limited category of victims, it was justifiable to impose a duty of care on police to warn or

(1990), 74 OR (2d) 225 (H Ct J) [Doe].

Part I of the Constitution Act, 1982, being Schedule B to the Canada Act 1982 (UK), 1982, c 11.

RSO 1980, c 381, s 57, as repealed by Police Services Act, RSO 1990, c P.15, s 42.

Doe, supra note 11 at 230. See also Project 360 Investments Limited (Sound Emporium Nightclub) $v$ Toronto Police Services Board, 2009 CanLII 36380 (Ont Sup Ct J) [Project 360 Investments], where Justice MacDonnell concluded that there was no proximity between police and a nightclub where a suspected gang member shot another patron. Although the gang member had been under police surveillance, there was no indication that he had any connection with the nightclub or that he intended to go there on the night of the shooting. 
protect women in the plaintiff's position. On the findings at trial, the police had done neither. ${ }^{16}$

Although Doe has not been directly affirmed by appellate courts, ${ }^{17}$ its concept of a "narrow and distinct group of potential victims" has guided the Canadian courts' analyses in subsequent cases of police liability for failure to protect. Thus, for example, where the police are aware of a known perpetrator and a known victim, there might be sufficient proximity to find a duty of care. This occurred in Mooney v. British Columbia (Attorney General), ${ }^{18}$ where there was a long history of domestic violence suffered by the plaintiff at the hands of her common-law husband. While he was still on probation for a violent attack on the plaintiff, he chased her through town in his vehicle. The plaintiff, fearing for the safety of herself and her children, immediately went to complain to police. Unfortunately, the officer assigned to her case did nothing to assist her, but simply advised her to consult a lawyer about obtaining a restraining order and to stay in public places in the meantime. Several weeks later, the plaintiff's estranged husband broke into her home, shot and killed her friend, injured her daughter, and then killed himself. The plaintiff sued police for their failure to take action in the face of a known threat.

The police argued that the officer's statutory duty "to preserve the peace and prevent crime is owed to the public at large and ... not to individual citizens." 19 Further, there was no justification for imposing an affirmative duty of care: the officer had not assumed responsibility to protect the plaintiff, nor had he worsened her position. Accordingly, the police argued that there was no proximity. Justice Collver found these arguments to be unpersuasive, and referred to Doe, the province's proactive policies with respect to domestic violence, and an internal disciplinary finding that the officer's conduct fell below investigative standards. ${ }^{20}$ The officer knew that the plaintiff had been attacked by her husband before, that he had been flagged as a violent person in the police information system, and that the plaintiff feared for her safety. These circumstances were sufficient to establish a proximate relationship and a duty of care.

Although Ms. Mooney's case ultimately failed on the element of causation, the British Columbia Court of Appeal did not disturb the trial judge's finding on the duty of care. ${ }^{21}$ As discussed below, this sets the Canadian law apart from the English approach to similar cases where the plaintiff is an identifiable victim of a known perpetrator. Justice Donald (dissenting), the only judge to discuss the duty of care in detail at the Court of Appeal, explained that the plaintiff "sought police assistance and had a direct engagement with an

Doe v Metropolitan Toronto (Municipality) Commissioners of Police (1998), 39 OR (3d) 487 (Ct J (Gen Div)) [Jane Doe]. The plaintiff was awarded over $\$ 220,000$ in damages.

See e.g. Hill v Hamilton-Wentworth Regional Police Services Board, 2007 SCC 41, [2007] 3 SCR 129 at para 27 [Hamilton-Wentworth], where Chief Justice McLachlin expressly distanced her decision from that in Doe. Hamilton-Wentworth involved the duty of care owed by police to those who are singled out as criminal suspects, which is distinguishable from the duty owed to crime victims.

2001 BCSC 419, 2001 BCSC 419 (CanLII) [Mooney SC], aff'd 2004 BCCA 402, [2004] 10 WWR 286 [Mooney CA], leave to appeal to SCC refused, 30546 (3 March 2005).

Mooney SC, ibid at para 43 (referring to statutory duties in the Police Act, RSBC 1996, c 367, s 7(2)). Mooney SC, ibid at paras 45-50.

Granted, the duty of care question was addressed only summarily by the majority of the Court of Appeal, which preferred to base its decision on the causation issue. See Mooney CA, supra note 18 at para 138. For further analysis, see Erika Chamberlain, "Tort Claims for Failure to Protect: Reasons for (Cautious) Optimism Since Mooney" (2012) 75:2 Sask L Rev 245. 
officer when she presented her complaint. She had a pressing need for protection as a potential victim of [her husband's] violence and the police should have recognized that. She cannot be said to fall into a large indeterminate class." 22 This gave rise to a relationship of proximity. Justice Donald further reasoned that, in any event, the Canadian courts had taken a broad approach to proximity in police liability cases, imposing a duty in cases as long as there is a threat to an identifiable class, as in Doe.

A similar analysis was undertaken in Castle v. Ontario, ${ }^{23}$ where the perpetrator, Reid, was known to be violent and had attacked the plaintiff in the past. On the day in question, Reid was severely intoxicated and had caused a disturbance at a local fair. This was in breach of a condition of his probation, which required him to keep the peace and be of good behaviour. The police did not arrest him, but instead took him to his father's home, where the plaintiff also lived. Reid stabbed and killed the plaintiff later that day. Justice Lederman found a sufficient relationship of proximity between police and the plaintiff, noting that police were aware of Reid's previous attacks on the plaintiff and that the two men lived together. This put the plaintiff within the narrow group of Reid's potential victims.

While both Mooney and Castle involved identifiable victims who were known to police, the courts in other cases have taken an even more expansive approach to the concept of proximity. In Haggerty Estate (Litigation Administrator of) v. Rogers, ${ }^{24}$ Justice Turnbull refused to strike out an action against the Hamilton Police Services Board by the estate of a man who was stabbed to death by a wanted criminal at a nightclub. A week before the stabbing, the criminal had apparently called 911, indicating that he wanted to turn himself in and asking for police to pick him up. The dispatchers advised the caller to turn himself in at the nearest police station; officers were dispatched an hour later to the location identified by the caller, but he had purportedly left by the time they arrived. No further action was taken to arrest the wanted man until the stabbing of the plaintiff.

In examining the proximity between the plaintiff and the Police Services Board, Justice Turnbull distinguished the case from situations where public authorities were found to owe duties only to the public at large, like Cooper and Eliopoulos. ${ }^{25}$ Instead, he found the case more analogous to Just v. British Columbia, ${ }^{26}$ where it was held that the provincial authorities responsible for inspecting and maintaining highways owed a duty of care toward a motorist whose car was struck by a boulder that fell from a rocky slope adjacent to the highway. Justice Turnbull used Just to counter the defendant's argument that there could be no duty of care in Haggerty because the specific identity of the plaintiff was not known to police. In Justice Turnbull's view, the plaintiff in Haggerty was in no different position from the many unknown motorists who were put at risk by the defendant's negligence in Just. He concluded that "it is not plain and obvious that the Plaintiff cannot succeed in showing that the failure to establish and/or implement procedures to deal with 9-1-1 calls from violent offenders or other known people who may pose a significant risk to members of the community may not found a valid cause of action." ${ }^{27}$ Justice Turnbull concluded that the case was closer to the

Mooney CA, ibid at para 46.

2014 ONSC 3610, 121 OR (3d) 46.

2011 ONSC 5312, 89 CCLT (3d) 256 [Haggerty].

Ibid at para 51 .

[1989] 2 SCR 1228.

Haggerty, supra note 24 at para 56. 
Doe end of the spectrum of police liability cases (having a narrow and distinct class of potential victims), noting that the plaintiff allegedly had a pre-existing relationship with the wanted criminal and that the two men were "arguably ... in geographic proximity.",28

Haggerty represents a notable extension of the principles of Doe and Mooney. While there was a known perpetrator, there was no reason for police to suspect that the plaintiff was a target of his violence. Indeed, there was not even an obvious class of potential victims, apart from those who might come into contact with the perpetrator in locations where he socialized from time to time. Justice Turnbull appears to have been influenced by the fact that police took very little action to arrest a known criminal. That is, rather than focusing on the proximity between the police and the plaintiff, Justice Turnbull focused on what he viewed as an operational failure on the part of the Police Services Board to implement appropriate procedures to apprehend criminal suspects with a proclivity for violence.

A similar motivation and broad approach to proximity were evident in the recent case of Patrong v. Banks, ${ }^{29}$ where Justice Myers found that police owed a duty of care to a 19-yearold man who was shot in a drive-by shooting by a known gang member, Riley. There were two court orders prohibiting Riley from entering Scarborough; nevertheless, surveillance officers did not stop him from entering Scarborough on the day that he shot the plaintiff. In a decision that strains, somewhat painfully, to explain the duty of care in lay terms, Justice Myers attempted to align the allegations in Patrong with those in Doe. The plaintiff was a young black man who lived in the Malvern area of Scarborough, and police had "carded" him on several occasions because they suspected he might be a gang member. ${ }^{30}$ Thus, Justice Myers reasoned, the plaintiff fit within the narrow class of Riley's potential drive-by shooting victims (rival gang members in the Malvern area). This removed him from the general public or the vast group of unidentifiable crime victims, and created a relationship of proximity to the police.

The defendant had argued that black teenage males who dress like gang members did not amount to a sufficiently distinct class to give rise to a relationship of proximity. ${ }^{31}$ Justice Myers disagreed. The judge pointed to the potentially incongruous conclusion that a real gang member would have a better claim to proximity than the plaintiff, on account of the fact that gang members were more identifiable shooting targets for Riley. ${ }^{32}$ Justice Myers intuitively sensed that this was wrong:

How can it make sense that negligence that allows an inherently dangerous act - a drive-by shooting — can be actionable by an intended victim if known to the police, but the police are always immune to a claim by a random victim, where their negligence is in allowing a situation that, by its nature, has horrible and often random, unintended outcomes? ? $^{33}$

Ibid at para 72. Somewhat curiously, Justice Turnbull struck out the claims against the 911 operators and the two officers who were dispatched to the location identified by the 911 caller (ibid at para 71). 2015 ONSC 3078, 19 CCLT (4th) 115 [Patrong].

Ibid at para 52.

Ibid at para 55

Ibid at paras $57-58$

Ibid at para 60. Presumably, the same analysis would allow recovery for other unintended victims of a drive-by shooting, such as children. 
Unfortunately, Justice Myers proceeded from this visceral sense of injustice to a somewhat convoluted invective against the existing state of the duty of care analysis, and ultimately fixed on the idea that a duty of care should lie where it is "just and fair" for the defendant to compensate the plaintiff. ${ }^{34}$ The "just and fair" test stems from the Supreme Court's decision in Cooper ${ }^{35}$ and from the House of Lords' decision in Caparo Industries plc $v$. Dickman, ${ }^{36}$ but does not have the precise meaning that Justice Myers attributed to it. The House of Lords used "fair, just and reasonable" as shorthand for the various policy factors that might be raised to negate a prima facie duty of care, and the Supreme Court used it largely as a conclusion flowing from the closeness of the relationship between the plaintiff and defendant. ${ }^{37}$ In other words, it is because the parties are in a sufficiently close relationship that it is just and fair to impose a duty of care.

In contrast, Justice Myers tended to use the phrase in a more colloquial sense to reflect a lay sense of injustice. He identified the "real issue" in the case as, "should the police compensate the plaintiffs if their story is true." ${ }^{38}$ Under his preferred approach, this requires a rather holistic examination of justice and fairness in light of, inter alia, the nature and quality of the wrong, the public nature of the defendants, causation, and the imminence of the harm. ${ }^{39}$ Justice Myers concluded by arguing that Doe had been interpreted too narrowly, and by generally criticizing the common law's treatment of public authority negligence liability. ${ }^{40}$ In this he expressed agreement with Justice Stratas' decision in Paradis Honey Ltd. v. Canada (Minister of Agriculture and Agri-Foods), ${ }^{41}$ where it was suggested that tort law be abandoned in cases involving public authority defendants and replaced with a system of public compensation or discretionary damages on judicial review. ${ }^{42}$

While Justice Myers' sympathy for the plaintiff and his frustration with the current duty of care jurisprudence is understandable, his analysis left much to be desired. The Cooper framework, while imperfect, at least creates an orderly methodology for duty analyses. It encourages courts to examine factors that might create a close and direct relationship between the plaintiff and defendant, including physical closeness, any previous interactions, representations by the defendant, or reliance by the plaintiff. It also requires courts to consider any statutory obligations that might give rise to a private law duty of care or, alternatively, indicate that the defendant has to balance competing interests against those of the plaintiff. It may well be that this analysis would yield the result that Justice Myers favours, given that Patrong involved a known perpetrator and victims were confined to a relatively small geographic area ${ }^{43}$ However, it would be retrograde to disregard the existing framework in favour of what the court intuitively views as "just and fair" in the circumstances, an approach that apparently subsumes questions of policy, fault, and causation. Further, it would be massively disruptive to introduce an entirely separate

Ibid at paras $61 \mathrm{ff}$.

Supra note 2 at para 34.

[1990] 2 AC 605 at 618 (HL (Eng)) [Caparo].

Ibid.

Patrong, supra note 29 at para 75.

Ibid at para 78 .

Ibid at paras 75-78.

2015 FCA 89, 382 DLR (4th) 720

For commentary on that decision, see Erika Chamberlain, "When Unlawfulness Becomes Tortious: Misfeasance in a Public Office and Administrative Law" (2015) 44:4 Adv Q 489 at 505-507.

Justice Myers admitted as much in Patrong, supra note 29 at para 78, where he wrote that the plaintiff's claim would be available under the standard private law analysis. 
framework for compensation in cases involving public authority defendants. As other scholars have explained, proposals to create a special regime of public tort liability require a much more thorough examination than can be undertaken in a monograph, let alone a motions application. ${ }^{44}$

Fortunately, while Justice Myers' analysis is questionable, the result in Patrong is not significantly at odds with the trend in Canadian cases alleging police failure to protect. There has been an increasing tendency to find sufficient proximity to ground a duty of care, especially where the perpetrator is known to police. The class of potential victims to whom a duty might be owed has been expanded beyond individual targets to include those who might be mistaken for intended targets (Patrong) and those who frequent locations where the perpetrator might be found (Haggerty). The courts' decisions seem at least partially influenced by the failure of police to apprehend suspects when they have a reasonable opportunity to do so. Through these failures, the police can be taken to have brought themselves into a closer relationship with the individuals to whom the suspects pose a risk of harm. Finally, Justice Myers' decision is illustrative of the proximity test's inherently complicated mixture of questions involving factual closeness and questions involving policy. This has the potential to be both the genius and the downfall of the proximity test.

\section{Proximity in English Police Liability Cases}

The English law dealing with police liability for failure to prevent crime is almost entirely at odds with the Canadian position. The English courts have declined to find sufficient proximity between police and plaintiffs, even when the perpetrator and victim are known and the harm is imminent. As discussed below, the courts have held fast to the traditional common law rule that there can be no liability for omissions or for failure to protect a plaintiff from harms caused by a third party. They are also loyal to the Diceyan principle that public authorities owe no greater duties in tort law than any other defendants. ${ }^{45}$ Thus, while police services have been established to protect the public, and police have the power to take action to protect victims and apprehend suspects, they generally have no obligation to do so that is enforceable at private law.

The English law in this area is largely governed by the House of Lords' well-known decision in Hill v. Chief Constable of West Yorkshire. ${ }^{46}$ The claim was brought on behalf of the last victim of Peter Sutcliffe (aka the Yorkshire Ripper). It was argued that police had negligently conducted the investigation into the series of murders and attempted murders that

See especially Geoff McLay, "What are We to Do With the Public Law of Torts?" Book Review of Towards a Public Law of Tort by Tom Cornford, (2009) 7:2 New Zealand J Intl Public L 373. McLay wrote that articulating the principles of a public law compensation system "is not the work of one book but the work of many" (ibid at 385). See also Peter W Hogg, Patrick J Monahan \& Wade K Wright, Liability of the Crown, 4th ed (Toronto, Ont: Carswell, 2011) at 208ff; Carol Harlow, "Rationalising Administrative Compensation" [2010] Public L 321; United Kingdom, Law Commission, Administrative Redress: Public Bodies and the Citizen, Law Com No 322 (London: The Stationery Office, 2010), Parts $2-3$.

45 See AV Dicey, Introduction to the Study of the Law of the Constitution, 10th ed (London, UK: Macmillan \& Co, 1964) ("every official, from the Prime Minister down to a constable or a collector of taxes, is under the same responsibility for every act done without legal justification as any other citizen" at 193). So-called Diceyan equality has long been at the heart of the common law's treatment of public authority defendants, suggesting that they are subject to the same rules of liability - no more and no less - as every other citizen. 
Sutcliffe committed between 1975 and 1980 and that, had the police not been negligent, Sutcliffe would have been apprehended before he killed Ms. Hill. The House of Lords struck out the action on the grounds that there was no duty of care owed by police to the plaintiff. Perhaps most famously, Lord Keith enumerated a series of policy considerations which served to negate any potential duty of care, including the risk of defensive policing, interference with police discretion, and the misallocation of police resources to the task of defending negligence claims by crime victims ${ }^{47}$ However, the decision in Hill also rested on a finding that there was insufficient proximity between the police and the plaintiff. Lord Keith wrote that Hill "was one of a vast number of the female general public who might be at risk from [Sutcliffe's] activities but was at no special distinctive risk in relation to them." He explained:

\footnotetext{
Miss Hill cannot for this purpose be regarded as a person at special risk simply because she was young and female. Where the class of potential victims of a particular habitual criminal is a large one the precise size of it cannot in principle affect the issue. All householders are potential victims of an habitual burglar, and all females those of an habitual rapist. ${ }^{49}$
}

The fact that Sutcliffe's victims were young and female was not sufficient to create an identifiable class.

While Hill has been subject to some exceptions, ${ }^{50}$ its general principles have maintained their force, even in cases where the plaintiff is from a narrow class of potential victims. In Smith v. Chief Constable of Sussex Police, ${ }^{51}$ the plaintiff had been assaulted by his estranged partner, who was taken into custody but not prosecuted. The plaintiff subsequently received numerous threats from his partner and reported these to police, explaining that he feared for his life. The police did not take notes about Smith's complaints or complete a crime form, but instead made rather slow and useless attempts to trace the relevant phone calls. Eventually, Smith's partner came to his home and attacked him with a claw hammer, leaving him with a fractured skull and brain damage. Lord Hope, for the majority, acknowledged that there was "a highly regrettable failure to react to a prolonged campaign ... threatening the use of extreme criminal violence." ${ }^{, 52}$ Nevertheless, relying on what he referred to as the core principle from Hill, he concluded that it would not be in the public interest to impose a duty of care, as a private law duty would lead to defensive practice and impede the ability of police to carry out their public functions. ${ }^{53}$ In other words, "the interests of the wider community must prevail over those of the individual." ${ }^{, 4}$

\footnotetext{
Ibid at 63-64.

Ibid at 62 .

Ibid.

See e.g. Swinney v Chief Constable of Northumbria Police Force (1996), [1997] QB 464 (CA) (police had assumed responsibility for the safety of an informant); Costello $v$ Chief Constable of Northumbria, [1999] ICR 752 (CA) (police inspector stood by while a female constable was attacked by a prisoner in a police station cell).

Ibid at para 75. I have elsewhere criticized the majority's decision for its stereotypical portrayal of victims of domestic violence. For instance, Lord Hope opined that "not every complaint [of domestic violence] is genuine" (ibid at para 76), and Lord Carswell described such cases as involving "a degree of hysteria or exaggeration" (ibid at para 107). See Erika Chamberlain, "Negligent Investigation: Tort Law as Police Ombudsman" in Andrew Robertson \& Tang Hang Wu, eds, The Goals of Private Law (Oxford: Hart Publishing, 2009) 283 at 298.
} 
Lord Bingham dissented and would have found a duty of care in the circumstances. $\mathrm{He}$ set out what he called the "liability principle" as follows:

I would hold that if a member of the public (A) furnishes a police officer (B) with apparently credible evidence that a third party whose identity and whereabouts are known presents a specific and imminent threat to his life or physical safety, B owes A a duty to take reasonable steps to assess such threat and, if appropriate, take reasonable steps to prevent it being executed. ${ }^{55}$

Lord Bingham argued that this liability principle was consistent with the decision in Hill, where there was no identifiable perpetrator and no specific threat to the plaintiff. Conversely, in Smith, the plaintiff had direct, face-to-face meetings with the police, who assured him that an investigation was in progress. The closeness of the relationship between the plaintiff and defendants reinforced the public policy considerations in favour of a duty of care: "Mr Smith approached a professional force having a special skill in the assessment of criminal risk and the investigation of crime, a professional force whose main public function is to maintain the Queen's peace, prevent crime and apprehend criminals. He was entitled to look to the police for protection. ${ }^{, 56}$ Lord Bingham thus called attention to the incongruity of the majority's reasoning, which suggested that the greater public interest in keeping the peace precluded a duty of care toward individual victims of crime. The public duty of police rings hollow indeed if it cannot be relied upon by those whose safety is under imminent threat. ${ }^{57}$ For whom else is the peace being kept?

Most recently, in Michael v. Chief Constable of South Wales, ${ }^{58}$ the United Kingdom Supreme Court found that police did not owe a duty of care to a woman who had called emergency services to report that her ex-boyfriend had attacked her on finding her with another man, and that he had told her he would be returning to kill her. The operator told her to lock her doors and keep her phone on hand because the police would want to call her back. ${ }^{59}$ Unfortunately, on transfer to another police department, the call was downgraded as only requiring a response within 60 minutes. By the time police arrived at the plaintiff's home, they found her dead from a brutal stabbing. Police files revealed that the plaintiff had suffered domestic abuse by the hands of her ex-boyfriend for two years prior to her murder, and had reported at least four violent incidents to police. Thus, Michael presented a case involving a known perpetrator, a known victim, and an apparently credible threat of imminent harm. This would seem to give rise to a proximate relationship.

However, the Supreme Court characterized the plaintiff's claim as involving a careless omission, which normally does not give rise to a duty of care. Lord Toulson noted that the two main exceptions to this rule are: (1) when the defendant is in a position of control over

Smith, ibid at para 44 .

Ibid at para 60 .

The other Lords also criticized Lord Bingham's liability principle on the grounds that it could not be constrained in a principled way - for example, why would it cover threats to physical safety but not to property? Such arguments border on offensive, as they downplay the severity of interpersonal violence. More practically, it seems quite obvious that the common law affords greater protection to some interests than others, as the cases governing pure economic loss and psychiatric harm attest. There is nothing unreasonable in suggesting that police have a greater duty to protect life and safety than to protect property. 
the perpetrator (such as a prison inmate); and (2) when the defendant has an obligation to safeguard the plaintiff (for example, employer-employee, school-pupil, health professionalpatient).$^{60}$ The first did not apply because the perpetrator was at large, and Lord Toulson refused to expand the second category to include the plaintiff's situation. He reasoned that the relevant police duty is their public duty to keep the Queen's peace, and that this could not be used to create a private law duty to individual victims, even if they were specifically identifiable to police. ${ }^{61}$ It is a duty "owed to members of the public at large, and does not involve the kind of close or special relationship ('proximity' or 'neighbourhood') necessary for the imposition of a private law duty of care." 62

Lord Kerr and Lady Hale dissented. Lord Kerr built on the liability principle expounded by Lord Bingham in Smith, but took greater pains to explain the element of proximity. $\mathrm{He}$ noted that the concept was nebulous and sometimes circular; however, it entails a close association between the plaintiff and defendant, whether in terms of physical, temporal, relational, circumstantial, or causal proximity. ${ }^{63}$ Lord Kerr also stressed the overlap and interrelatedness of the elements of proximity and of what is fair, just and reasonable in the circumstances. He wrote, "[p]ut simply, if there is proximity, this is likely to have a bearing on whether it is fair to impose liability." relationship, it is highly unlikely to be just and fair to impose a duty of care.

In cases alleging police failure to protect, Lord Kerr would assess proximity "by a close examination of all the circumstances with a view to discovering whether sufficient information has been conveyed to or is otherwise available to the police to alert them to the urgent need to take action which it is within their power to take. That the information be specific and the threat imminent are prerequisites of the proximity relationship." ${ }^{, 65}$ On the facts in Michael, a proximate relationship existed because there was an identifiable perpetrator who had already attacked the plaintiff and who, as she told the emergency dispatcher, was planning to return imminently to kill her. Lord Kerr questioned what more could possibly be required to create a proximate relationship with police. ${ }^{66}$

Further, to the extent that the majority viewed the case as being governed by the traditional rule that there can be no liability for omissions, Lord Kerr viewed their reasoning as misguided. The omissions principle is often justified on the basis that imposing a duty to rescue or protect is a greater limitation on the defendant's freedom than imposing a duty not to cause harm. While this may be true of private citizens, Lord Kerr questioned its application to a police force, which is established for the precise purpose of protecting citizens. Police hardly have unlimited autonomy. In this respect, Lord Kerr was influenced by a review paper by Stelios Tofaris and Sandy Steel, which was published just prior to

Ibid at paras 119-20. Lord Toulson asked, for example, how the court would decide a case where a known criminal shoots his intended victim as well as a bystander. Would police owe a duty of care to the former but not the latter? (ibid at para 120).

Ibid at para 120 .

Ibid at paras 144-46 (including a reference to Justice Deane's well-known passage in Sutherland Shire Council v Heyman (1985), 60 ALR 1 at 55-56 (HCA)).

Michael SC, ibid at para 156. See also ibid at para 158.

Ibid at para 168 .

Ibid at para 173 . 
Michael and called for reform of police liability for failure to prevent crime ${ }^{67}$ Borrowing from their paper, Lord Kerr wrote: "Whereas it is arguable that a private individual's freedom has an intrinsic value in its contribution to an autonomous life, the value of the state's freedom is instrumental and lies in the contribution that it makes to the fulfilment of its proper functions." ${ }^{\prime 68}$ Bruce Feldthusen has made a similar observation: "Autonomy is a personal value, not an institutional one." ${ }^{69}$ It does not promote the public interest to suggest that a publicly-funded police force should have the freedom not to respond to credible threats of imminent violence.

In addition to their critique of the omissions principle, ${ }^{70}$ Tofaris and Steel suggested that proximity should be found in police liability cases where the following four elements are satisfied:

(i) The claimant is at a special risk of personal harm...

(ii) The police are aware or should reasonably have been aware that the claimant is at a special risk of personal harm.

(iii) The police are given special powers by law to protect the class of persons to which the plaintiff belongs...

(iv) The claimant is dependent upon the police as regards to protection against the risk. ${ }^{71}$

With respect to the fourth element, Tofaris and Steel note that a victim is vulnerable "in the sense that she cannot be reasonably expected to protect herself adequately against [the] risk." 72 Victims understandably rely on police to protect them against violent offenders. Tofaris and Steel argue that the "combination of the police's special status and the victims' dependency on them when threatened by a third party with a criminal act militates in favour of recognising that the police may potentially be liable in negligence in such cases.",73

Importantly, Tofaris and Steel reject the requirement that there be some assumption of responsibility by police before a duty of care can be recognized. They point to Lord Slynn's decision in Phelps v. Hillingdon London Borough Council, where he described assumption of responsibility as an objective test and noted that "[i]t is not so much that responsibility is assumed as that it is recognised or imposed by the law."74 That is, a duty can be imposed even if there are no statements or actions by which the defendant affirmatively assumes responsibility for the plaintiff's interests. This interpretation would dispense with the pedantic observations by the Court of Appeal in Michael about whether the operator's

Stelios Tofaris \& Sandy Steel, "Police Liability in Negligence for Failure to Prevent Crime: Time to Rethink" (2014) University of Cambridge Faculty of Law Legal Studies Research Paper Series No 39/2014, online: $<$ ssrn.com/abstract $=2469532>$.

68 Michael SC, supra note 58 at para 177 (referring to Tofaris \& Steel, ibid at 6).

69 Bruce Feldthusen, "Tilting the Balance of Power Between the Courts and Government Through the Common Law of Negligence" (2015) ResearchGate Working Paper 16/07/2015.

See Tofaris \& Steel, supra note 67 at 5-9.

Ibid at 23 [footnotes omitted] [emphasis omitted].

Ibid.

Ibid at 18 [footnote omitted].

[2001] 2 AC 619 at 654 (HL). 
suggestion that the police would call the plaintiff and that she should keep her phone free amounted to an assumption of responsibility by authorities. Lord Longmore referred to these statements as a "routine expression of expectation that South Wales police force would call her not an assurance that they would." 75 It is difficult to understand how a woman who is (rightly) in fear for her life should make this distinction and determine whether she can rely on police to take reasonable steps to protect her. Indeed, one would hope that the necessity of police action is beyond doubt in the circumstances.

\section{ANALysis}

The police liability cases in Canada and England help shed light on the utility and content of the proximity requirement for the duty of care. By their own admission, the courts in both jurisdictions have struggled to define proximity in a useful way. For example, in Caparo, Lord Bridge wrote that "the concepts of proximity and fairness embodied in these additional ingredients are not susceptible of any such precise definition as would be necessary to give them utility as practical tests, but amount in effect to little more than convenient labels." In Canadian National Railway Co. v. Norsk Pacific Steamship Co., Justice La Forest wrote that "[t]he proximity test has practically no predictive value" "77 with respect to relational economic loss, and Justice McLachlin acknowledged: “[p]roximity may be usefully viewed, not so much as a test in itself, but as a broad concept which is capable of subsuming different categories of cases involving different factors." discard the concept of proximity altogether because "it neither states, nor points to, any relevant principle that assists in the resolution of disputed questions about the existence of a duty of care, beyond indicating that something more than foreseeability of damage is necessary." 79

Nevertheless, the Canadian courts have developed a growing list of factors that are relevant to the proximity analysis. In Cooper, the Supreme Court provided a list that included expectations, representations, reliance, and the type of interests involved. ${ }^{80} \mathrm{~A}$ court is more likely to find proximity when there is a personal relationship between the parties, and when vital interests of the plaintiff are at stake. ${ }^{81}$ In police failure to protect cases, the Canadian courts have fleshed out proximity so that it includes considerations of whether there is a narrow class of potential victims, an identifiable perpetrator, and whether the victim or perpetrator have had previous contact with police. ${ }^{82}$ In almost all of the cases where a duty of care was found, vital interests of the plaintiff (life and personal security) were at risk. ${ }^{83}$

Michael CA, supra note 58 at para 22.

Caparo, supra note 36 at 618 .

[1992] 1 SCR 1021 at 1130, La Forest, dissenting.

Ibid at 1151.

Miller v Miller, [2011] HCA 9, 242 CLR 446 at para 60.

Cooper, supra note 2 at para 34.

See Hamilton-Wentworth, supra note 17 (the majority noted the important interests at stake for the suspect of a criminal investigation, such as "his freedom, his reputation and how he may spend a good portion of his life" at para 34 ).

Where there is no such prior contact or no reason to believe that the plaintiff is a potential victim, there may be insufficient proximity: see Project 360 Investments, supra note 14.

By contrast, there was no duty of care owed by police in Spencer $v$ Canada (Attorney General) et al, 2010 NSSC 446, 304 NSR (2d) 1, where a man was released from police custody and subsequently set fire to his family home. While the man had previously assaulted his wife, it was unforeseeable that he would cause property damage. But see McClements v Pike, 2012 YKSC 84, 99 CCLT (3d) 270, where Justice Gower refused to strike out an action against police by a woman whose daughter burned down 
These cases are capable of providing at least some meaningful guidance on proximity for future claims.

At the same time, the police liability cases demonstrate the inherent complexity of proximity, which subsumes policy considerations in its more concrete discussion of physical, relational, and circumstantial closeness. The underlying policy considerations that influence the proximity analysis are evident in the central role played by the relevant statutory framework. This is explicitly mandated by Cooper, which forces the courts to consider the proposed duty of care in light of the other obligations owed by a public authority. In the case of police, the courts have acknowledged that the overarching police duties to keep the peace, investigate crimes, and apprehend suspects involve a balancing of many competing interests. Obviously, the police cannot prevent all crimes from occurring, and so will not generally owe a private law duty of care to individual victims of crime. One can imagine the flood of litigation that would occur if any crime victim could sue police because they could have done something more to prevent the crime in question.

However, where the victim or the perpetrator is known to police, and where physical harm to the victim is imminent, there may be sufficient proximity to impose a duty of care. This conclusion is consistent with the Supreme Court's statement in Cooper that the various proximity factors "allow us to evaluate the closeness of the relationship between the plaintiff and defendant and to determine whether it is just and fair having regard to that relationship to impose a duty of care in law upon the defendant." ${ }^{24}$ That is, the closer the relationship between plaintiff and defendant, the fairer it is to impose a duty of care. While it would be unjust and unfair to impose a duty of care on police toward the vast population of potential crime victims, the same is not true in cases where the perpetrator, victim, and threat are known to police. Indeed, the judges in recent cases have stressed that it is completely just and fair to impose liability on police where they fail to take effective action to prevent foreseeable crimes against foreseeable victims. ${ }^{85}$

The same is not true in England, where the courts have repeatedly declined to find a duty of care in cases involving police failure to protect. Quite apart from the dubious policy considerations that are regularly cited in support of police immunity, the English courts' analysis of proximity in these cases seems, at best, disingenuous. It was one thing to deny proximity in Hill, where the perpetrator was unknown and at large, and where large sections of the public were at risk. However, Smith involved a plaintiff who reported to police that his estranged partner, who had assaulted him before, was threatening him with violence. He had direct interactions with officers, who purported to begin an investigation. Similarly, Michael involved a victim who had previously reported domestic abuse to police and had

the family home. The daughter, who was extremely intoxicated at the time, had told authorities that she intended to burn down the house once police left the scene.

84 Cooper, supra note 2 at para 34. The Court also wrote that the relational factors associated with proximity "include questions of policy, in the broad sense of that word" (ibid at para 30)

The Canadian courts are not alone in this respect. See e.g. Batchelor v Tasmania, [2005] TASSC 11, 13 Tas R 403, where Justice Blow of the Supreme Court of Tasmania refused to strike out an action against police by a boy whose father killed his mother and then committed suicide. The mother had complained to police on the day of the shootings that her husband had seriously assaulted her, intended to kill her, and owned firearms. Contrary to the pro-arrest policy then in place, police did not arrest the husband (who was at the police station), but told him that they were going to his home to seize his firearms. When they arrived, they noticed that one of the firearms was missing, but left the mother alone inside, where she was shot by her husband through a window. 
called emergency services to report an imminent threat on her life. Neither of these plaintiffs was a member of the vast general public; they were specific targets of known perpetrators, and had made direct contact with police. These factors would seem to point to a "close and direct" relationship.

Nevertheless, as explained, the proximity analysis is deeply infused with policy considerations, including whether the common law should recognize an affirmative duty to rescue or protect plaintiffs from the criminal acts of third parties. The majority in Michael placed great emphasis on the traditional rule that there is no duty of care with respect to omissions, and supported its argument with a rather technical application of Dicey's equality principle. Lord Toulson went to some lengths to establish that police owe no greater private law duties to protect victims of crime than any other citizen. The fact that the government has established a police service does not mean that their failure to rescue or protect victims should give rise to compensation. Lord Toulson cited the decisions in Stovin $v$. Wise ${ }^{86}$ and Gorringe v. Calderdale Metropolitan Borough Council ${ }^{87}$ to explain that the police liability cases are most appropriately characterized as ones where the defendants simply failed to "confer a benefit" on the plaintiff; that is, failed to exercise their powers in a way that might have prevented the plaintiffs' losses ${ }^{88}$ Crime victims do not have a general private law right to demand assistance, and police should have no greater liability than any other individual who fails to prevent them from suffering harm. ${ }^{89}$

Notwithstanding that this approach has been consistently endorsed by the House of Lords, the UK Supreme Court, and some leading tort scholars, ${ }^{90}$ it is extremely difficult to justify its application in cases like Michael. As Tofaris and Steel argue, "[t]he fact that we do not and ought not to have such a right [to assistance] good against the whole world need not imply that we ought not to have such a right good against some limited class of wellpositioned potential duty-bearers in limited circumstances. ${ }^{.91}$ Can the court really suggest that police owe no private law duty to a woman who has called emergency services to report a credible and imminent threat on her life by a man who has, to the knowledge of police, abused her in the past? Are the police under no greater obligation to assist her than any other citizen? And of what use is a police service that cannot be relied upon by people in the plaintiff's position? Tofaris and Steel suggest that the failure to recognize a duty "would destabilise the legal framework that prescribes a citizen's acceptable response and delineates the police's role in cases of violent threats." 92

[1996] AC 923 (HL (Eng)) (failure of highway authority to remove a bank of earth that obstructed the view at an intersection, leading to a number of accidents).

[2004] UKHL 15, [2004] 2 All ER 326 (failure of highway authority to provide warnings for drivers to slow down when cresting a dangerous hill).

Michael SC, supra note 58 at paras 108-11. This line of reasoning is consistent with the rights-based approach to tort law espoused by Robert Stevens, which postulates that plaintiffs can only bring claims against defendants who have breached their legally-protected rights. In Stevens's view, the fact that a public authority has the power to do something does not give individuals an enforceable private law right to have the power exercised in a way that would have prevented their injuries: Robert Stevens, Torts and Rights (Oxford: Oxford University Press, 2007), ch 10.

Lord Toulson distinguished police from some other public services (for example, health care and education), where the same private law duties would be owed by a public provider as by a private provider: Michael SC, ibid at para 112.

See Stevens, supra note 88; Donal Nolan, "The Liability of Public Authorities for Failing to Confer Benefits" (2011) 127:2 Law Q Rev 260.

Tofaris \& Steel, supra note 67 at 8.

Ibid at 18 . 
It is noteworthy that the Supreme Court in Michael was presented with arguments about the extent of domestic violence in the UK and the generally poor response of police to these situations. ${ }^{93}$ In 2014, Her Majesty's Inspectorate of Constabulary published a report on police response to domestic abuse that was critical in many respects, including risk assessment, first contacts with victims, and the prioritization of domestic abuse relative to acquisitive and organized crime. ${ }^{94}$ The report stressed that "[i]t is important that when a victim contacts the police they have confidence that their call will be acted upon." 95 Indeed, Michael raises questions of reliance and its role in establishing proximity against those who provide services to the public. If police cannot legitimately be relied upon, citizens may need to resort to private security or vigilante justice. This can hardly be in the public interest. It is particularly disheartening for those who are especially vulnerable to violence.

In this respect, one cannot ignore that so many of the failure to protect cases, in Canada and England, have involved situations of domestic, sexual, or racialized violence. For the most part, the Canadian courts have taken this as an opportunity to comment on the sometimes inappropriate or stereotypical attitudes of police toward these groups of victims. In Jane Doe, for example, Justice MacFarland wrote that the police investigation "was motivated and informed by the adherence to rape myths as well as sexist stereotypical reasoning about rape, about women and about women who are raped." ${ }^{\prime 96}$ The alleged police negligence often involves the low priority assigned to the plaintiffs' complaints (as in Mooney, Smith, and Michael) or that police were more concerned about monitoring the perpetrator than protecting potential victims (as in Doe and Patrong).

In terms of the proximity analysis, these cases reflect on the vulnerability of the plaintiffs and their reliance on police for their safety. In some cases, proximity is enhanced by special guidelines or policies that directly address the need for police to be proactive in situations involving domestic violence. For instance, in Mooney, Justice Donald made extensive reference to the proactive arrest and charge policies in place in British Columbia, which informed the "special proximity between police and complainants." ${ }^{97}$ In fact, he suggested that the plaintiff brought herself into a relationship of proximity with police by reporting her fears of abuse. ${ }^{98}$ Her complaint triggered the obligation to act, which was supported by official policy.

Further, to the extent that the proximity analysis is informed by questions of policy, it is not inappropriate to consider the special vulnerability of certain victims, especially where there is a historic pattern of discounting their complaints. To absolve police of liability on account of the omissions principle in these cases is an implicit approval of their historic inaction: it suggests that they really do not have any obligation to protect victims of domestic or sexual violence. In addition, it suggests that the victims are not entitled to rely on police for their safety, even in the face of credible, imminent threats. To borrow Lord Atkin's

Supra note 58 at para 19. See also Smith, supra note 51 (also involving a claim of intimate violence). United Kingdom, Her Majesty's Inspectorate of Constabulary, Everyone's Business: Improving the Police Response to Domestic Abuse (London: HMIC, 2014) at 6-10.

Ibid at 39 [emphasis added].

Supra note 16 at 521. See also Lady Hale's decision in Michael SC, supra note 58 at para 198, where she noted regretfully that some of the inappropriate police attitudes toward domestic violence had crept into the jurisprudence as well.

Supra note 18 at para 50.

Ibid at para 57 . 
famous opinion: "If this were the result of the authorities, I should consider the result a grave defect in the law, and so contrary to principle that I should hesitate long before following any decision that effect." 99

\section{Conclusion}

The police liability cases present a useful microcosm for examining the proximity element of the duty analysis and comparing its application in Canada and England. They demonstrate that the statutory context is of relatively little use in determining whether proximity exists. On their face, the statutory duties imposed on police are aimed at protecting the public at large; however, the public is ill-protected by a police force that fails to respond to threats against individual citizens. It is through individual interactions that the public duty is fulfilled. The police liability cases also highlight the importance of reliance, vulnerability, and personal interactions between the police and the perpetrator or victim to the proximity analysis.

At a more challenging level, these cases illustrate the complexity of the proximity inquiry and its ambiguous combination of factual closeness and policy considerations. This conflation underlies the apparent confusion in some courts' examination of proximity. In Patrong, for example, it was the judge's intuitive sense of injustice that led him to extend proximity to a wider class of potential victims or plaintiffs than had previously been recognized. Conversely, the English courts have denied proximity even in the face of imminent threats by a known perpetrator against a known victim on the grounds that imposing a private law duty would interfere with the public interest and contradict the traditional rule that there is no liability for omissions. In the end, while the cases make admirable attempts to meaningfully apply the proximity test, they show that proximity is not so much a legal concept as a social and political one. 
This page is blank - do not strip it in 